\title{
Trade Off Ethics Of Colonial Lecturers And Milenial Students In Critical Thinking In Indonesia Technology University (Uti) - Bali
}

\author{
Dwi Sihwinarti \\ Universitas Teknologi Indonesia (UTI) Denpasar \\ wiwin.ipd@gmail.com
}

\begin{tabular}{|l|}
\hline \multicolumn{1}{|c|}{ Published: 30/03/2020 } \\
\hline How to cite (in APA style): \\
$\begin{array}{l}\text { Sihwinarti, D (2020). Tourism Finance: Trade Off Ethics Of Colonial Lecturers And Milenial Students In Critical Think- } \\
\text { ing In Indonesia Technology University (Uti) - Bali.. Jurnal Ekonomi dan Bisnis Jagaditha, 7(1), 1-8. doi: https:// } \\
\text { doi.org/10.22225/jj.7.1.1651.1-8 }\end{array}$ \\
\hline
\end{tabular}

\begin{abstract}
This study aims to find out the Ethics of Colonial Lecturers to understand Millennial students in communicating to be able to unite their perceptions, to find out Millennial Student Ethics hold and uphold custom and culture as a guideline in communicating or democracy critically in the education and community environment to create creative ideas in innovation, and to find out the Ethical Trade Off of Colonial Lecturers and Millennial Students in Critical Thinking to improve Communication and Teaching and Learning processes in the campus environment. This research was conducted through direct experience and observation in teaching. The research method used is descriptive qualitative approach and phenomenology. The main informants are 4 students and 2 lecturers. This research was conducted at Indonesia-Bali University of Technology campus. The research results obtained that through a personal approach and understanding, the character of millennial students and treating them as a friend, friend and even a child, from a lecturer, were able to make positive changes in the world of education. Because they feel valued and even given the opportunity to express their opinions and develop creative ideas, but within the boundaries of good ethics in accordance with eastern customs that we have. So that millennial children have a character that can bring them into critical thinking to grow and develop and innovate in accordance with technology.
\end{abstract}

Keywords: Critical Thinking, colonial Lecturers, millennial Students, trade Off Ethics

\section{INTRODUCTION}

If we realize that we are currently in the Era of the Industrial Revolution 4.0, it will ring in our ears about the Millennial Generation which always fills and colors the world of education. This can be seen through the campus environment that is colored by the Millennial Student's behavior in the educational pattern, where a lecturer must be able to understand the character and desires of millennial students if they want to be successful as teaching staff. While this situation is inversely proportional to the principle of the Colonial lecturer, where a student must respect an older person in daily life and not make him a friend, friend and even partner for discussion.

Difficult for a colonial lecturer in the era of technological development as it is today in understanding Millennial Students to be able to unite the perception of the teaching and learning process, if it still maintains its old principle that is that the lecturer is always right and must be respected and feared, not respected. Whereas for millennial students the mindset used is that what is done or desired must be in accordance with their wishes without thinking about the causal effects that will occur, so that it clashes with what is called Ethics. Because Ethics is a critical reflection on how humans should live and act in concrete situations, certain special situations. Where Ethics is also a moral philosophy or science that discusses and critically examines issues of morally right and wrong (Keraf, 2002). This situation causes the difficulty of teaching and learning process can run well in accordance with technological developments, because in this context between lecturers and students alike maintains their respective principles 
without the existence of a solution that can solve the problem because of the existence of egoism and ethic which is meaningless. When referring to the Kamus Besar Bahasa Indonesia, the word ethics is explained by distinguishing three meanings, they are knowledge about what is good and what is bad and about moral rights and obligations (morals), collection of principles or values regarding with morals, values regarding the right and wrong of a group or society. Thus, in this case there needs to be an agreement that can realize the Vision of education.

Wherein the vision is the realization of the education system as a strong and authoritative social institution to empower all Indonesian citizens to develop into qualified human beings so that they are able and proactively respond to the ever-changing challenges.

Critical thinking is needed very much to develop one's mindset in opinionating and determining attitudes, but critical thinking must also be based on ethical elements so as not to become a boomerang or a misstep. Because to find a solution of the problems faced, it is certainly necessary to think critically that can produce new or creative ideas, not only knowledge but also requires a broad insight. Critical thinking is a way of thinking logically, where we solve a problem into several parts, which then analyze it. Where part of critical thinking is the ability to classify, sort, and compare similarities and differences (Church \& Harahap, 1993). Critical Thinking is an important thing for every human being in life as capital to analyze and solve a problem faced in order to get the desired solution. (Wartoyo, 2019) concluded that to create competent communication, motivation, knowledge and skills are highly needed. Where these three things are the main components, so it can be analyzed whether the communicator is competent or not in any situation.

Problems in communication that occur at UTI-Bali today, where most of the students have worked, but these students are still classified as millennial age so that it often leads to misperceptions in communication and ethics. This has led to frequent misunderstandings between lecturers and students, where a lecturer is required to be able to understand and understand the situation and condition of the student who in the context of development always wants to use technology as his mainstay but is not based on good ethics. Thus, for a lecturer, especially a colonial lecturer (who was born in the range of 1946-
1964: Baby Boomer, and 1966-1980: Generation $\mathrm{X}$ ), it is natural that he still wants to maintain his old cultural principles to be respected and comply with every regulation made, so students can follow it.

This situation makes the researchers to conduct further research on how to obtain solutions to these problems so that the teaching and learning process can run well, in accordance with the wishes and corridors of education without ignoring the culture of Ethics but still following the development of existing technology.

This study aims to find out the Ethics of Colonial Lecturers to understand Millennial students in communicating to be able to unite their perceptions, to find out Millennial Student Ethics hold and uphold custom and culture as a guideline in communicating or democracy critically in the education and community environment to create creative ideas in innovation, and to find out the Ethical Trade Off of Colonial Lecturers and Millennial Students in Critical Thinking to improve Communication and Teaching and Learning processes in the campus environment.

\section{CONCEPTUAL FRAMEWORK}

\section{Trade Off}

When we hear the word Trade Off, of course there are many problems that can be solved with the solution, because the sentence has the meaning as "Exchange". Where the exchanges made in this case are mutually sacrificing something to find an agreement for one specific purpose. Trade Off can also be interpreted as a sacrifice that we do to give up something we like or have in order to get something else from an exchange that makes us feel happy for what was done. The same thing was expressed by (Mankiw N, Quah, \& Wilson, 2012), to get something we want, we usually have to give up or give up something else that is also valuable to us. If we have many goals, we must let go of some of the goals in order to pursue the specific goals we most want, because decision making requires us to give up one goal to get another goal. As what we remember about the concept of scarcity (scarcity) that human desires are relatively unlimited, while the means of satisfying those desires are very limited. In other words, where the means of fulfilling desires is not sufficient to fulfill all desires that are not limited, so to get the means of satisfying these desires requires another sacrifice. 


\section{Ethics}

According to (Harisusanto, 1989) that ethics is a good living habit that is passed down from one generation to another. Where Ethics is understood as a teaching that contains rules about how humans should live a good life as humans. Ethics is also a teaching that contains commands and prohibitions about how good or bad human behavior. In the education environment of the Ethics campus, it is very necessary to expedite the teaching and learning process so that it can run well and in accordance with eastern cultures that always prioritize manners or courtesy in communicating or behaving. According to (Keraf, 2002) that ethics as a critical reflection on how humans should live and act in concrete situations and certain special situations. Because Ethics is a moral philosophy, or science that discusses and critically examines issues of right and wrong regarding one's behavior morally. Where, Aristotle, the great Greek philosopher distinguishes ethics into three types, namely Descriptive Ethics, Native Ethics, and Meta-Ethics.

Descriptive Ethics is Ethics that studies moral behavior in a broad sense, such as customs, views about good and bad, actions that are required, permitted or prohibited in a community or campus environment (Latif, 2013). Meanwhile, normative ethics does not merely describe, but to give clues about good and bad, may or may not (Nurdin, 2014). According to the (Latif, 2013) that the Mate Mate-ethics that is known does not discuss moral issues in the good or bad sense of a behavior, but he is more concerned with moral language. For example, if an action is considered good, then the question is: what is the good meaning in the action, what are the measurements and conditions for being called good and so on. Therefore, it is important for a student in controlling himself very closely related to what is called Ethics. Because with ethics students are able to control every activity or action that has a bad influence such as demonstration and anarchist actions that can harm themselves and others, especially in the era of globalization. Where there are many changes made in the development of science and technology and economic recovery of life that leads to quality and lifestyle as well as changes in the values of moral norms.

It is important for campus institutions in this case to be able to direct and foster their students in a positive direction in ethics, so that the teaching and learning process carried out can go well as expected. Therefore, it is necessary to have a regulation set by the campus institution that can be used as a guide for students to carry out their activities so as not to deviate from the specified corridor.

Here are some student ethics that need to be applied on campus, including:

Obey the rules set by the Faculties and Lecturers who educate you.

Regarding fellow students as peers who must help each other and consider them as recipients of assistance in competing for academic achievement.

Upholding scientific honesty by obeying applicable scientific principles. Like, avoiding cheating, tracing, falsifying, demanding, and other despicable acts.

Behave politely and politely in getting along on campus and in the community as a manifestation of maturity in thinking and acting.

Look elegant in accordance with current fashions without having to oppose discipline on campus.

Think critically, rationally and scientifically in accepting new knowledge. It means to consider what is right and what is wrong by replying to each input by confirming it to the source.

Having a clear principle in education is based on humility without having to appear arrogant or arrogant. (https:// www.dkampus.com> eti ...)

\section{Colonial Lecturer}

The lecturer is a person who teaches in a tertiary institution. Where, the profession for a lecturer is a noble task in terms of getting involved in educating the quality and ethical education of the nation's children. Lecturers are also obliged to be able to run what is called Tri Darma Perguruan Tinggi : 1) Education 2) Research and Development 3) Community Service. Of the three Tri Darma number one is Education, where education is related to ethical education of students both within the campus and in the community in shaping the character and character of their students. This is in accordance with Law No.20 of 2003 stating that education is a conscious and planned effort to create an atmosphere of learning and learning process so that students actively develop their potential to have spiritual spiritual strength, self-control, personality, intelligence, noble character and the skills needed by himself, the community, the nation and the state. Whereas for a lecturer, 
especially a colonial lecturer who was born in the range of 1946-1964 which is often referred to as the Baby Boomer generation and 19661984 called Generation X, of course it needs extra adjustments, because not all lecturers are able and able to follow technological developments which are developing, especially in understanding the wishes of millennial students. So that there is a need for socialization among the lecturers to get the best solution for every problem faced in the campus environment so that there are no longstanding misunderstandings. Where, Lecturers are professional educators and scientists with the main task of transforming, developing, and disseminating science, technology, and art through education, research, and community service (Based on RI Law Number 14 of 2005 concerning Teachers and Lecturers). Therefore, it is fitting for a professional lecturer to hold fast to Ethics in conducting academic activities so that harmony in the education takes place and does not arbitrarily impose regulations on students.

\section{Millennial Students}

When talking about millennial students, it is no stranger to us that this generation is the $\mathrm{Z}$ generation born in the years 1995-2010. The Prew Research Center defines Millennial as a person born from 1981, with no final boundary determination. Meanwhile, according to demographers William Strans and Neil Howe define Millennial is born among 1982-2004. To be able to understand the ethics and desires of millennial children, of course there are many things that we must know in order to be able to harmonize with a world full of technological developments. Therefore, it would be nice if we first know about the characteristics of the International Generation that can be used as consideration in making a commitment for every decision that will be made for a particular purpose. Here are 10 Characteristics of Millennials according to Sinta: 1) Quick Bored of something (Easy to get bored with the items purchased). 2) "No Gadget No Life" 3) Having hobby to make non -cash payments. 4) Like the fast and instant. 5) Choose experience over Assets. 6) Different behavior in one group and another. 7) Good at Multitasking. 8) Critical to social phenomena. 9) Little posts. 10) But, for Millennial "Sharing is Cool". As a child or Millennial student in the technology era 4.0, in maintaining academic credibility, of course, it must also be able to make itself as a pride for many people so that in innovating or creating, they must also hold fast to what is called Ethics, both in behavior or in speech. As stated by Faisal Ismail below, "Be a Millennial Generation that is Visionary and Contributors of Modern Civilization but Character" (Like: Replay, Mark as Spam). Likewise, what Arjuna Cah Jawa said about the Millennial Generation, that this generation is a generation full of new ideas and extraordinary enthusiasm, has a sense of responsibility, dares to make decisions and is willing to accept risks. While the bad habits of the Millennial Generation Today are: 1) Gadgets Addiction 2) Consumptive Lifestyle 3) Tutorial Generation 4) Instant Love 5) Less socializing. http://www.mogloger.com. Thus, as a mirror of the academic community that upholds the values of humanity and politeness, students must respect themselves, others, and the academic environment in which they will interact in the learning process. In fact, education does not only aim to develop science, but also shape personality, independence, social skills, and character (Zuchdi, 2011).

\section{Critical Thinking}

Critical thinking is an ability to think clearly possessed by someone rationally about what is done about something that is believed to be the ultimate truth. (Elia, 2016) said that Critical Thinking (or Critical Thinking) is an ability to think clearly and rationally about what to do or what you want to believe to be true.

Whereas (Ennis, 2011) states that critical thinking is reasonable and reflective thinking focused on deciding what to believe or do (critical thinking is a relative thought process that focuses on deciding what is believed to be done). So, to be able to think critically of course there are things in basic principles must meet certain criteria that can direct us towards what will be done. Likewise, with the opinion of (Lipman, 1991) who defines critical thinking as thinking that can facilitate decisions based on real criteria, which are selfcorrective and substantive in context.

In the world of education, especially the campus environment, where most of the students are Millennials, critical thinking is needed to be able to develop their mindset about knowledge and insight which is expected to be able to bring about positive changes in addressing every problem faced in an era of increasingly sophisticated technological change. Therefore, it is necessary to have an introduction or understanding of how the characteristics of the academic community which in its context can be used as a reference 
for making changes in the campus environment in a better teaching and learning process.

The characteristics of the academic community are critical, objective, analytical, creative and constructive, open to accepting criticism, respecting time and scientific achievements, free from prejudice, dialogical partnership, having and upholding academic norms and ethics and scientific traditions, dynamic, and future oriented (Widyanto, 2007).

\section{METHODS}

In this research the method used is descriptive qualitative approach and phenomenology on campus. Qualitative research is a research procedure that produces descriptive data in the form of written or oral words from people and observable behavior and phenomena that occur (Moleong, 2008). The main informants were 4 students and 2 lecturers. This research was conducted through direct experience in the teaching and learning process and observation for approximately 4 semesters at the Indonesia-Bali University of Technology campus.

\section{RESULTS AND DISCUSSION}

We have to admit that millennial kids these days are indeed very clever in accepting and processing something about technological development. But because of the many technological advances that exist in various kinds of science, making it difficult for them to digest and direct what is good and what is bad. Therefore, the task for a lecturer or educator in this case is to direct and foster them so that every technological development must be addressed properly through a screening process or selection that is really strict so that what we want to do have positive and ethical goals. Similarly, the system or pattern of teaching and learning of a lecturer must be able to inspire students to grow and develop into independence. This can be done by a lecturer or educator by collaborating between material and business practices that exist in the world of work. We tried and implemented the system or pattern at the same time practicing it directly in 4 semesters with positive responses from students and proved to be able to increase about $85 \%$ student interest in learning at the UTI-Bali campus. We certainly follow this with other systems such as providing a high percentage of attendance for students by $30 \%$ which aims to train students in discipline, and participation in class by $25 \%$ with the aim of providing opportunities for them to dare to express their opinions critically according to knowledge and the insights they have while still putting forward good and right ethics, considering that the UTI campus is mostly independent students. To strengthen the relationship between lecturers and students of course also need personal approaches both in communication and ethics and openness that leads to the process of teaching and learning to be more productive and innovative as expected. By holding a number of activities such as channeling student talent (Arts and Culture, language skills, Entrepreneurship that refers to Fintech), cleaning in the campus environment which then continues outside the campus environment and is carried out in a relaxed atmosphere full of intimacy between lecturers and students, is expected able to make new contributions to academics while also inviting them to socialize with the community as a form of concern for the world of education for the surrounding environment in the midst of technological developments in the millennial era.

Understanding the character of students is one of the most important things in the world of education so that lecture material delivered by lecturers can be understood and understood properly and correctly so that it can be digested by each student. If a lecturer or educator is able to understand the character of his students, then this is one of the solutions in solving a problem caused by a communication error that occurs in the world of education, especially the millennial era to be able to help expedite the teaching and learning process at the campus. There are things that need to be changed from the mindset of a Colonial lecturer in the world of education as it is today, for example how to treat students no longer have to always obey and obey every rule we make and assume that what is done by a lecturer is always right. But some must be maintained as a principle, such as how younger people can still respect and respect older people, in the context of Etic.

Likewise, from Millennial Students who must also be defended, but there is also something that needs to be improved from the nature or mindset in the Now era, as now, which is to want something that is instantaneous and less sociable with the surrounding environment because it is fun playing gadget. Therefore, so that everything can go hand in hand, it takes a sacrifice that can make it all be aligned as a generational change but still adhere to the Ethics and 
customs of our ancient ancestors. With a situation like this, where between lecturers and students can understand and mutually sacrifice something that is considered very principle for each individual to get an agreement with a better goal is the right action in solving the problem that is happening. This is in accordance with (Elistia, 2017) that a trade-off is a situation where a person must make a decision on two or more things, sacrificing / losing an aspect with a certain reason to obtain other aspects with different qualities as choices made. Likewise, Keller's opinion in (Kim, 2007) which has a slightly different view and states that the trade-off is between attributes, benefits and attitudes or values.

Teaching and learning process in the digital era, for a lecturer, especially a colonial lecturer should be able to change the mindset about the views on millennial children. To be able to carry out the teaching and learning process well in the 4.0 era with all the technological developments, of course it takes a different perspective and treatment from a lecturer to students, where we must be able to make them as friends, friends and even parents for their students so that they feel comfortable if you will share complaints about what is being faced and will get a positive solution, because they feel appreciated. A lecturer or educator should no longer be an authoritarian, who will only make students feel afraid and subject to any given rules, so that it will hamper the teaching and learning process and even make it difficult for them to develop creative ideas. The current democratic system can certainly be implemented and upheld in the world of education, but in the context or boundaries that have been set according to agreements made wisely. This is expected to be able to bridge the aspirations of students and lecturers in solving a problem for a positive purpose. Openness in various matters can certainly make our students or students become more mature in thinking to face various problems both in the campus and society. Because education is a business that is more aimed at developing character, conscience, passion, love, morality, piety, and others Darmodiharjo in (Sabdulloh, 2010). Likewise, for a colonial lecturer, of course it is also expected to be able to evaluate them and learn to be disciplined in the application of the knowledge they have in order to benefit the education world properly. As stated by (Susanto \& Wijanarko, 2005), that educating is conveying teachings, norms and values of life, rules and laws. Where Wijanarko's view is emphasized again by Waini Rasyidin in his writings on Critical Pedagogics, elaborating on the notion of educating as an activity to guide the growth of children, physical and spiritual intentionally not only for the sake of teaching now but for future life (Zahir, 2011).

Many kinds of characters and personalities of students that we often encounter and face in the world of education every day, sometimes we as lecturers or educators must succumb and tolerate in front of them so that our existence can be accepted and can mingle with millennials. Since this Millennial child was born after Generation X, where their age range between 17 to 37 years old born in 1980 to 2000, of course, is very different from the people of the Colonial era or Baby Boomers, both in terms of characteristics, thought patterns and habits in daily behavior. Therefore, coaching of student ethics is something that should be given attention in shaping character for the world of education so that the millennial child is not one of the steps in responding to any existing development. As explained by (Suyitno, 2012) that character can be interpreted as innate, heart, soul, personality, character, behavior, personality, character, character, temperament, and character. The development of increasingly sophisticated technology sometimes makes someone forget about the existence of cultural civilization or mutual respect for older people and their neighbors both in the campus environment and the community in real life which is the basis for democracy. As stated by Franz Magnis Suseno in (Suyitno, 2012) at the National Workshop on the Development of Cultural and National Character Education, said that in this era, it is needed not only young people with strong character, but also true, positive and constructive. Where, the statement is interpreted that indeed for now character education becomes a very important thing to be transformed to students. It must also be acknowledged that the Millennial Generation is very clever in accepting and using technology and their perspective is more instant now but always creative and innovative. Lyons in (Putra, 2016) explains about the millennial generation, where this generation uses a lot of instant communication technologies such as email, SMS, instant messaging and social media like Facebook and Twitter, in other words Generation $\mathrm{Y}$ is the generation that grew up in the booming internet era. Therefore, it is also important to teach and instill for millennial children about the noble values of the meaning of a strong brotherhood between each other as one 
manifestation of the Unity in Diversity, so that there is no division. Through patience and never give up, as well as the high enthusiasm of the colonial lecturers and millennial students in working together to support each other for a positive change is expected to realize the world of education in Indonesia to be more advanced to grow and develop in accordance with today's digital technology.

Critical thinking for students in the world of education is something that we should appreciate because they want to advance and develop in accordance with technology in order to be able to innovate using their creative ideas to realize an inspirational and productive Millennial Generation. But we also need to know that universities have two main elements, namely lecturers and students. Both of these elements need to have an orientation towards the development of academic culture. Both are bound in academic ethics which grow from noble values and lead to the formation of academic culture. According to (Santoso, 2011), it should be understood that the background of all the elements that exist and more closely observed the external dynamics of the campus. In its implementation, the core activities of higher education are Tridarma Perguruan Tinggi, so that all educational, research, and community service activities are carried out with character. Exchange ideas and cooperate in accepting all kinds of fields of science in accordance with technological advances, it should be done by a lecturer with students which is one of the best ways to understand every problem faced by millennial children so that our presence can be accepted and able to make them create brilliant ideas as a forum for young people in creating creative work and innovating in the midst of the work industry competition. (Wibowo, 2013) explained in detail that character education in higher education has the following functions. First, the formation and development of student potential means efforts to shape and develop Indonesian people and citizens who think, have a heart, and behave well in accordance with the philosophy of Pancasila. Second, improvement and strengthening, namely efforts to improve the character of humans and citizens of Indonesia that are negative and strengthen the role of families, educational units in universities, society and government, to participate and take responsibility in developing the potential of humans or citizens, towards a nation of character, developed, independent, and prosperous. Third, as a filtering tool, which is an effort to sort out the values of the nation, and filter the positive cultural values of other nations to become fully human characters and Indonesian citizens. Through this process of character screening, students are expected to become part of this nation that has noble, intellectual and dignified character. By creating a slogan that can motivate and illustrate the enthusiasm of young people today, "Keep Moving My Young Generation, Millennials Who Never Give Up to Create Ideas and Distribute it to the Creative Industries for the Educating of the Indonesian Nation", are expected to be able to bring a change that is positive in the world of academic education in general and the UTIBali campus in particular.

\section{CONCLUSION}

To be able to grow and develop in the world of education in accordance with the technology of the digital era, it requires critical thinking from both colonial lecturers and millennial students about how to unite perceptions that can facilitate the process of teaching and learning in the campus environment. Where one of them is by way of a personal approach to be able to understand the character of millennial students and treat them like friends, friends or a child to feel valued, so that respect arises towards parents who can ultimately be accepted as a civilization in ethics or behave and speak words. With the solution of every problem that exists in order to reach an agreement and succumb to each other's ego for a new goal to be achieved, it was able to bring positive change in the world of education.

\section{REFERENCES}

Church, A. H., \& Harahap, Z. (1993). Pompa dan Blower Sentrifugal. Jakarta: PT. Erlangga.

Elia, Y. (2016). Critical Thinking (Berpikir Kritis): Sebuah Pengantar. Retrieved from https:// zilbest.com/filsafat/critical-thinking-berpikir -kritis-sebuah-pengantar/

Elistia. (2017). Ekonomi Mikro (Hubungan Pelaku Ekonomi Dalam Perekonomian). Jakarta: Universitas Esa Unggul.

Ennis, R. H. (2011). The Nature of Critical Thinking: An Outline of Critical Thinking Dispositions and Abilities. University of Illinois. Retrieved from https:// education.illinois.edu/docs/default-source/ faculty-documents/robert-ennis/ thenatureofcriticalthinking_51711_000.pdf

Keraf, S. (2002). Etika Lingkungan. Jakarta: Buku Kompas.

Kim, K. H. (2007). Creativity. Singapore: World Science Publishing. 
Latif, M. (2013). Pendidikan Anak Usia Dini. Jakarta: Kencana Prenada Media Group.

Lipman, M. (1991). Thinking in Education. UK: Cambridge University Press.

Mankiw N, G., Quah, E., \& Wilson, P. (2012). Pengantar Ekonomi Mikro: Edisi Asia. Jakarta: Salemba Empat.

Moleong, L. (2008). Metodologi Penelitian Kualitatif: Edisi Revisi. Bandung: PT. Remaja Rosdakarya.

Nurdin, F. (2014). Pengantar Filsafat. Magelang: Panta Khei Books.

Sabdulloh, U. (2010). Pedagogik Ilmu Mendidik. Bandung: Alfabeta.

Susanto, A., \& Wijanarko, H. (2005). Power Branding: Pembangunan Merek Unggul dan Organisasi Pendukungnya. Jakarta: PT. Nizan Publika.

Suyitno, I. (2012). Pengembangan pendidikan karakter dan budaya bangsa berwawasan kearifan lokal. Jurnal Pendidikan Karakter, 2 (1).

Wartoyo, F. (2019). Etika Komunikasi Mahasiswa dan Dosen dalam Perspektif Akademis Revolusi 4.0. WASKITA, 3(2). https:// doi.org/10.1017/CBO9781107415324.004

Wibowo. (2013). Manajemen Kinerja. Jakarta: Rajawali Press.

Zahir, A. (2011). Pengertian Pendidikan, Mendidik, Pembelajaran, \& Mengajar.

Zuchdi, D. (2011). Pendidikan Karakter dalam perpektif Teori dan Praktik. Yogyakarta: UNY Press. 